\begin{tabular}{|c|c|c|}
\hline 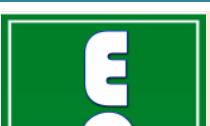 & $\begin{array}{l}\text { International Journal of Current Research in } \\
\text { Biosciences and Plant Biology }\end{array}$ & $=$ \\
\hline & Volume 6 • Number 9 (September-2019) • ISSN: 2349-8080 (Online) & \\
\hline $\begin{array}{l}\text { EXCELLENT } \\
\text { PUBLISHERS }\end{array}$ & Journal homepage: $\underline{w w w . j j c r b p . c o m}$ & \\
\hline
\end{tabular}

\title{
Leaf epidermal anatomy of selected varieties of Bambara groundnut in Gombe State, Nigeria
}

\author{
H. M. Abba*, B. A. Umar and I. Mohammed \\ Department of Biological Sciences, Gombe State University, Gombe, Nigeria \\ *Corresponding author; e-mail: halimamohammedabba77@gmail.com; Tel.: o8025509392.
}

\begin{tabular}{|c|c|}
\hline Arti & \multirow{5}{*}{$\begin{array}{l}\text { ABSTRACT } \\
\text { Leaf epidermal microscopy of five varieties of Bambara groundnut was studied to } \\
\text { investigate the structure of stomata and epidermal features which may be used for } \\
\text { delimitation of the species. Fresh matured leaves of five }(5) \text { different varieties of } \\
\text { Bambara groundnut (Vigna subterranea) namely red, white, black, strippe with brown } \\
\text { eye and strippe with black eye were obtained from the new Botanical Garden of } \\
\text { Biological Sciences Department adjacent Faculty of Science Complex within Gombe } \\
\text { State University, Gombe, Nigeria. The specimens were studied under light microscope } \\
\text { to examine the stomatal features, epidermal cell shapes and anticlinal cell wall patterns. } \\
\text { The results revealed the presence of hypo-amphistomatic leaves; two types of stomatal } \\
\text { complex type namely, paracytic and anomocytic. The frequency was } 100 \% \text { for red, } \\
\text { white, black and stripped brown; while stripped black had } 50 \% \text {. The highest stomatal } \\
\text { density ( } 83.33 \pm 39.17) \text { on the abaxial of stripped brown and lowest number } \\
\text { (34.00 } \pm 9.54) \text { on the adaxial of black varieties was observed. The stomatal size had } \\
\text { highest number of } 54.18 \pm 22.17 \text { on the adaxial of black and lowest number of } \\
24.10 \pm 6.31 \text { on the abaxial surface of stripped black. The stomatal index had highest } \\
\text { number on the abaxial surface of stripped black (9.47 } \pm 35.13) \text { and lowest number on the } \\
\text { abaxial surfaces of stripped brown (1.00 } \pm 24.11 \text { ). Straight and curved anticlinal cell wall } \\
\text { patterns with pentagonal and polygonal epidermal cell shapes, presence of trichomes } \\
\text { on the abaxial surfaces of red, white and black, and absence on both surfaces of } \\
\text { stripped brown and stripped black varieties were recorded. It was concluded that all the } \\
\text { varieties had water conserving properties, however, red variety had the highest water } \\
\text { conserving properties of having both small size of stomata and trichomes. These } \\
\text { features were found to be of good and reliable taxonomic use for delimiting the five } \\
\text { varieties of Bambara groundnut. }\end{array}$} \\
\hline & \\
\hline & \\
\hline Keywords & \\
\hline $\begin{array}{l}\text { Bambara groundnut } \\
\text { Leaf micro-morpholog } \\
\text { Stomatal index } \\
\text { Trichomes } \\
\text { Vigna subterranea }\end{array}$ & \\
\hline
\end{tabular}

\section{Introduction}

The Bambara groundnut (Vigna subterranea [L.] Verde.), belongs to the family Leguminosae and sub-family Papilionoideae. It is commonly known as 'nyimo' (Shona) or 'indlubu' (Ndebele), and gujjiya in Hausa language. It is an indigenous African legume whose origin is known from West Africa to extend from Jos in Plateau and Yola in Adamawa States of Nigeria to Garua in Cameroon, Central African Republic and Chad (Goli, 1995). In Southern Africa, Zimbabwe is the centre of 
production. It can also be found in tropical parts of America, Asia and Australia but the present degree of cultivation outside Africa is basically negligible. In Africa, it is the third most commonly eaten legume after groundnut and cowpea (Omoikhole, 2008). Vigna subterranea grows well where groundnut does not (Brink et al., 2006). Although the crop produces a nutritious food and is cultivated throughout Africa, it remains largely neglected by the scientific community. Nevertheless, empirical evidence and fragmentary research results suggest that it is a crop with great potential. Food legumes have a major role to play in the fight against malnutrition. It is therefore necessary that their levels of consumption, which are already too low in a number of developing countries should be increased (Borget, 1992).

The high carbohydrate $(65 \%)$ and relatively high protein of $18 \%$ content of Bambara nut make it a complete food (Doku, 1995). It is cultivated primarily for its seeds, which are used as human food. The seeds are used in many types of foods, some of which are an important part of human diets. Mature, dry seeds are boiled and eaten as a pulse. Seeds can be milled to make flour. Ripe seeds are very hard and must be cooked for longer than those of other legumes. Creamcoloured seeds are often preferred to red and black seeds, because they are less bitter and take less time to cook. Large seeds are preferred to smaller ones, especially for use as a snack. Smaller seeds are ground into flour for use in various recipes.

The processing of Vigna subterranea results in byproducts (shells or offals) that can be fed to animals. Seeds can also be fed to animals if surplus to human requirements. The leafy shoots are used as fodder (Brink et al., 2006). Bambara nut is resistant to high temperatures and can be grown on poor marginal soils not suitable for other leguminous crops (Yamaguchi, 1983). Bambara nut has a very low insect pest and disease susceptibility (Tweneboah, 2000) but can be affected by various fungal diseases. Like other legume plants, Vigna subterranea is a good soil fertilizer and a good rotation crop. It does not require any additional fertilizer. It is generally intercropped with cereals (maize, sorghum, and pearl millet), other pulses (cowpea, groundnut), and root and tuber crops.
Bambara groundnut has a spreading landraces/varieties and has a longer vegetative phase, takes longer to mature, and therefore suffers decline in yield due to the low soil moisture levels in the savannah zone. Late flowering also has a detrimental effect on seed yield of the Bambara groundnut in the savannah zone. Therefore there is need to study the micro-morphological characteristics of the plant to determine the variety that is the most drought resistant variety among the different varieties in the semi-arid regions of Nigeria. Leaf epidermis anatomy has been used repeatedly to classify and reclassify plants. Epidermal cells, such as trichomes, stomatal features and anticlinal cell wall patterns, are used. The epidermal cells and other appendages are less subjected to modification. So they serve as good taxonomic character. Several taxonomists have used these epidermal features to delimit plants within genera and families (Abdulrahaman and Oladele, 2003; Watson, 2006; Ren et al., 2007; Van Wyk et al., 2008; Hardie, 2009; Abdulrahman and Oladele, 2010; Saheed and Illoh, 2010; Zhigila et al., 2015; Abba et al., 2018).

\section{Description of the plant}

The Bambara groundnut [Vigna subterranea (L.) Verdc.] is a herbaceous, intermediate, annual, creeping legume. Leaves are pinnately trifoliate, glabrous with erect petiole, thickened at the base. Two stipels subtend the terminal leaflet, while only one is assigned to each of the two lateral leaflets. The oval leaflets are attached to the rachis with marked pulvini. The plant has a well-developed tap root with profuse geotropic lateral roots. The roots form nodules for nitrogen fixation, in association with appropriate rhizobia. Flowers are presented as Papilionaceous racemes. Once fertilized, the flower is drawn below the soil through a tunnel. Fruits are 2 or 3 -seeded pods, 1.5 to $3 \mathrm{~cm}$ long, wrinkled and at first indehiscent. Seeds are round, smooth and very hard when dry (Ecoport, 2009). Fruit development has been reported to be influenced by photoperiod (Linnemann and AzamAli 1993). Long photoperiods delay or even prevent fruit set in some cultivars. Flowering is considered day-neutral, but continuous light was shown to delay flowering by 6-11 days in a few genotypes (Nishitani et al., 1988). The pods usually develop underground, and may reach up to $3.7 \mathrm{~cm}$, depending on the number of seeds they contain. 
Most varieties have single-seeded pods, but pods with three seeds were frequently found in ecotypes collected in Congo (Goli and Ng, 1988). Mature pods are indehiscent, often wrinkled, ranging from a yellowish to a reddish dark brown colour. Average yields are $300-800 \mathrm{~kg} / \mathrm{ha}$, but can range from $100 \mathrm{~kg} / \mathrm{ha}$ up to $4 \mathrm{t} / \mathrm{ha}$.

\section{Varieties of Bambara groundnut}

There are two botanical varieties known as $V$. subterranea var. spontanea which includes wild varieties and $V$. subterranea var. subterranea which includes cultivated varieties. There are seven types of the Bambara groundnut cultivated varieties. The cultivars of Bambara groundnut has distinct differences ranging from cream through brown, maroon to black with variation in the seed sizes, and seed coats thickness (Nti, 2009). According to Directorate Plant Production (DPP, 2011), there are seven varieties of Bambara groundnut. The varietal differentiation is given below along with photographs (Fig. 1) of Bambara ground nut.

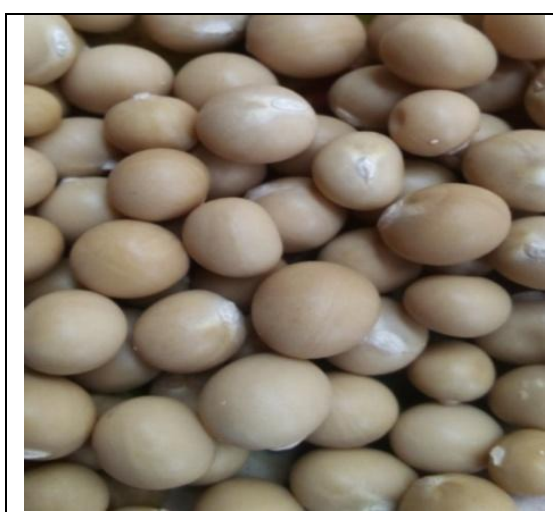

(A) Cream variety

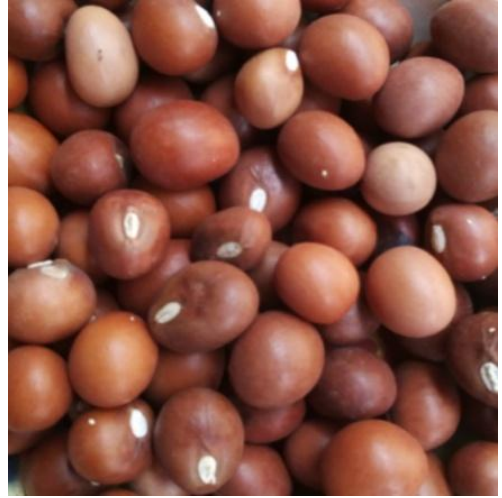

(B) Red variety

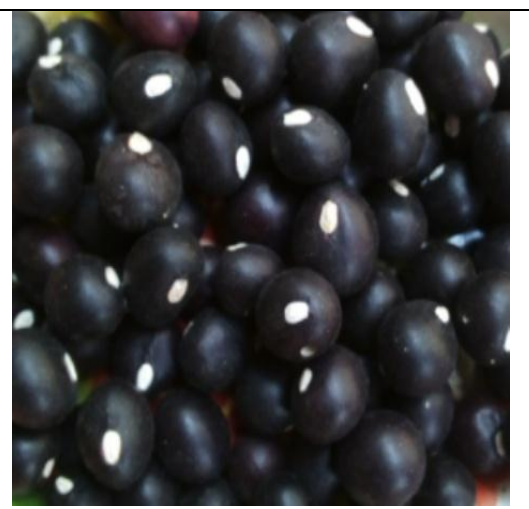

(C) Black variety

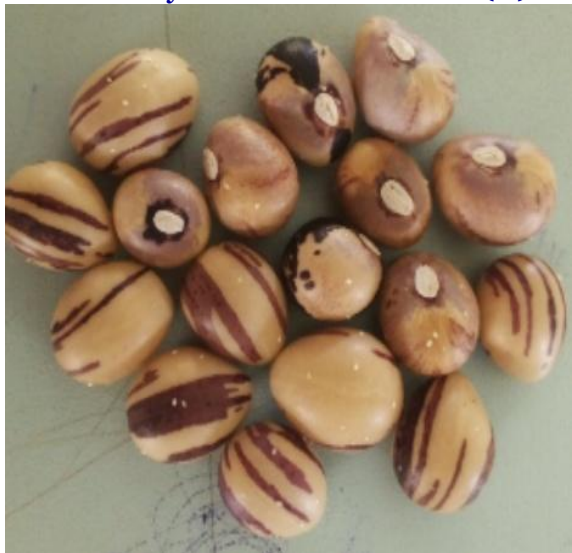

(D) Stripped brown variety

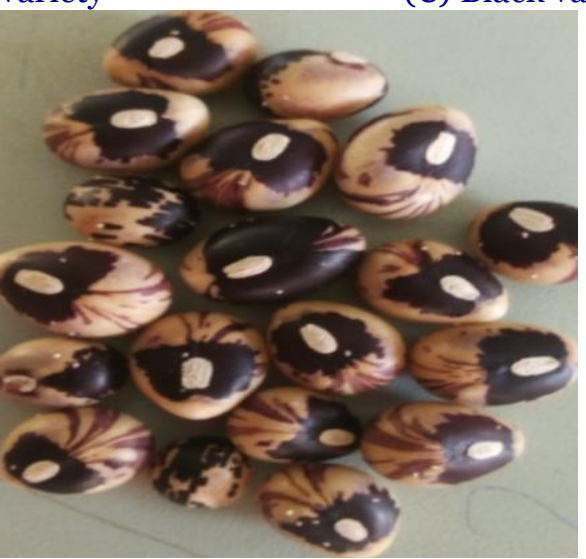

(E) Stripped black varieties

Fig. 1: Some varieties of Bambara ground nut.

Red variety: Late maturing. Kernels are large. A good yielder, however, it is prone to rotting on site. The seed coat is red in colour, it has a round shape, smooth, hard varying in size up to $1.5 \mathrm{~cm}$ brought hilum white (Nti, 2009).

Cream/no eye variety: Very small pods and kernels. It mainly produces one seed and yields are lower. The seed coat is cream in colour, round in shape, smooth, hard, varying in size up to $1.5 \mathrm{~cm}$, hilum white (Nti, 2009).
Black variety: Early maturing, usually small to medium-sized kernels. Mainly one-seeded. The seed coat is black in colour, seeds are round in shape, smooth, hard, varying in size up to $1.5 \mathrm{~cm}$, hilum white (Nti, 2009)

Cream/strippe brown eye variety: A moderate kernel and a good yielder. The seed coat is cream with strippe of brown, it is round in shape, smooth, hard, varying in size up to $1 \mathrm{~cm}$ broad hilum white (Nti, 2009) 
Cream/strippe black eye variety: A large kernel and a good yielder The seed coat is cream with strippe of black, they are rounded in shape, smooth, hard, varying in size up to $1.5 \mathrm{~cm}$ broad hilum white (Nti, 2009)

\section{Materials and methods}

\section{Plant collection and microscopic examination for epidermal study}

Fresh matured leaves of five (5) different varieties of Bambara groundnut (Vigna subterranea) namely red, white, black, stripped with brown eye and stripped with black eye were obtained from the new Botanical Garden of Biological Sciences Department adjacent to Faculty of Science Complex within Gombe State University, Gombe, Nigeria. The specimens were identified in the University Herbarium, Department of Biological Sciences, Gombe State University, Gombe, Nigeria. Leave samples were then fixed in Formalin Acetic Acid (FAA) and preserved in 70\% ethanol. Epidermal peels of the surfaces of the plant were made using the method of (Zhigila et al., 2015). The adaxial and abaxial surfaces of the leaves were carefully sectioned from the median portion of the leaves with razor blade (free hand section) and placed on a microscope clean glass slide. The preparation were stained with $1 \%$ aqueous solution of Saffranin for 4 to 8 minutes, and rinsed carefully in water to remove excess stain and then mounted in 10\% glycerol and observed under a light microscope and the leaf epidermal features were then examined using 35 fields of view at $\times 40$ objective as quadrats. The numbers of subsidiary cells per stomata was noted to determine the frequency of the different stomatal complex types and was expressed as percentage occurrence of such complex types based on all occurrences (Obiremi and Oladele, 2001). Terminologies for naming stomatal complex types followed (Dilcher, 1974). The Stomatal size/guard cells area of a species was determined as the product of length and breadth. The mean stomatal sizes/ guard cell area were determined by Francos constant method (Stomatal size/Guard cells area = length $\times$ breadth (width) $\times$ 0.7854) of guard cells using an ocular eye-piece micrometer and finally converted by the ocular constant with respect to the power with which they were taken. Samples of 35 stomata were used. The method followed those of (Franco, 1939; Wilkinson, 1979). The stomatal densities were determined by counting the number of stomata per micrometer view quadrat. Stomatal Index was determined as number of stomata per square millimeter divided by number of stomata plus number of epidermal cells per square millimeter multiplied by 100 (Dilcher, 1974). The stomata observed were viewed with the light microscope and were calculated in unit area using the Stomatal Index (S.I.) formulae as determined according to Metcalfe and Chalk (1979) as shown below.

$$
\text { S.I. }=\frac{\mathrm{S}}{\mathrm{S}+\mathrm{E}} \times 100
$$

Where,

S.I. = Stomatal Index

$\mathrm{S}=$ Number of stomata per unit area

$\mathrm{E}=$ Number epidermal cells in the same unit area

\section{Statistical analysis}

All data for epidermal study were processed using Analysis of Variance (ANOVA), Duncan's Multiple Range Test (DMRT) was used. A probability value of $0.05 \%$ was used as bench mark for significant difference between parameters.

\section{Results and discussion}

Table 1 shows the result of stomatal features of the five varieties (red, cream, black, stripped brown and stripped black) of Bambara groundnut. Stomata were observed on both leaf surfaces i.e., leaves were hypo-amphistomatic. Two types of stomatal complex types were observed in all five varieties i.e., paracytic and anomocytic type on both leaf surfaces.

The frequency were of two types i.e $100 \%$ for the red, white, black, and stripped brown varieties and $50 \%$ for stripped black variety.There were variations in the stomatal sizes $(54.18 \pm 22.17$ $26.18 \pm 7.46$ ) within the adaxial surfaces of black and the abaxial surface of stripped black. Stomatal densities $(83.33 \pm 39.17-34.00 \pm 9.54)$ within the abaxial surface of stripped brown and the adaxial surface of black. And the Stomatal index (9.46 \pm $35.31-1.00 \pm 24.11)$ was also variable between the abaxial surface of stripped black and the abaxial surface of stripped brown. It however has the highest number on the abaxial surface (9.46 \pm 35.31) in stripped black, and lowest on the abaxial surface $(1.00 \pm 24.11)$ in stripped brown. 
Table 1. Stomatal features in the five different varieties of Bambara groundnut.

\begin{tabular}{lllllll}
\hline Taxa & $\begin{array}{l}\text { Stomatal } \\
\text { Surface }\end{array}$ & $\begin{array}{l}\text { Stomatal } \\
\text { type }\end{array}$ & Frequency & $\begin{array}{l}\text { Stomatal } \\
\text { density }\end{array}$ & Stomatal size & $\begin{array}{l}\text { Stomatal } \\
\text { index }\end{array}$ \\
\hline Red & Adaxial & Paracytic & $100 \%$ & $35 \cdot 33 \pm 13.05$ & $26.62 \pm 8.49^{\mathrm{b}}$ & $5.20 \pm 1248.99$ \\
& Abaxial & Paracytic & $100 \%$ & $36.00 \pm 14.79$ & $29.29 \pm 9.48^{\mathrm{a}}$ & $6.10 \pm 1609.35$ \\
Cream & Adaxial & Paracytic & $100 \%$ & $42.33 \pm 20.03$ & $44.88 \pm 15.39^{\mathrm{a}}$ & $4.57 \pm 750.56$ \\
& Abaxial & Paracytic & $100 \%$ & $51.67 \pm 20.00$ & $41.24 \pm 15.49^{\mathrm{b}}$ & $8.43 \pm 4576.39$ \\
Black & Adaxial & Anomocytic & $100 \%$ & $34.00 \pm 9.54$ & $54.18 \pm 22.17^{\mathrm{a}}$ & $5.40 \pm 1907.89$ \\
& Abaxial & Anomocytic & $100 \%$ & $75.67 \pm 51.07$ & $53.47 \pm 17.24^{\mathrm{b}}$ & $1.00 \pm 5936.61$ \\
Stripped brown & Adaxial & Paracytic & $100 \%$ & $34.33 \pm 10.01$ & $30.73 \pm 5.92^{\mathrm{a}}$ & $5 \cdot 50 \pm 1212.44$ \\
& Abaxial & Paracytic & $100 \%$ & $83.33 \pm 39.17$ & $28.50 \pm 8.79^{\mathrm{b}}$ & $1.00 \pm 2411.08$ \\
Stripped black & Adaxial & Paracytic & $50 \%$ & $35.00 \pm 7.55$ & $26.18 \pm 7.46^{\mathrm{a}}$ & $7 \cdot 37 \pm 3082.74$ \\
& Abaxial & Anomocytic & $50 \%$ & $67.67 \pm 27.93$ & $24.10 \pm 6.31^{\mathrm{b}}$ & $9.47 \pm 3513.00$ \\
\hline
\end{tabular}

Table 2 shows the presence of polygonal shapes of epidermal cells on both leaf surfaces of red, cream, black, stripped brown and stripped black varieties, with straight and rounded anticlinal cell wall pattern (Table 2; Fig. 2). The highest average of epidermal cell density was recorded in the Bambara groundnut varieties on the abaxial surface (100.67 \pm 24.11$)$ and the lowest was

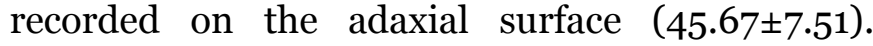
There was no wide range of epidermal cell wall pattern among the varieties. Trichomes were also observed. Trichomes were present on the abaxial surface of red, white and black varieties and absent on stripped black and stripped brown.

Table 2. Epidermal cells density, epidermal cell shapes, anticlinal cell-wall patterns and trichomes.

\begin{tabular}{llllll}
\hline Taxa & $\begin{array}{l}\text { Stomatal } \\
\text { Surface }\end{array}$ & $\begin{array}{l}\text { Epidermal cell } \\
\text { density }\end{array}$ & $\begin{array}{l}\text { Epidermal } \\
\text { cell shape }\end{array}$ & $\begin{array}{l}\text { Anticlinal cell wall } \\
\text { pattern }\end{array}$ & Trichomes \\
\hline Red & Adaxial & $52.00 \pm 12.49$ & Polygonal & Straight/curved & Absent \\
& Abaxial & $61.00 \pm 16.09$ & Polygonal & Straight/curved & Present \\
Cream & Adaxial & $45.67 \pm 7.51$ & Polygonal & Straight/curved & Absent \\
& Abaxial & $84.33 \pm 45.76$ & Polygonal & Straight/curved & $\begin{array}{l}\text { Present } \\
\text { Black }\end{array}$ \\
& Adaxial & $54.00 \pm 19.08$ & Polygonal & Straight/curved & Absent \\
& Abaxial & $100.00 \pm 60.26$ & Polygonal & Straight/curved & Present \\
Stripped brown & Adaxial & $55.00 \pm 12.12$ & Polygonal & Straight/curved & Absent \\
& Abaxial & $100.67 \pm 24.11$ & Polygonal & Straight/curved & Absent \\
Stripped black & Adaxial & $73.67 \pm 30.83$ & Polygonal & Straight/curved & Absent \\
& Adaxial & $94.67 \pm 35.13$ & Polygonal & Straight/curved & Absent \\
\hline
\end{tabular}

The result showed that the leaves of all the varieties were hypo-amphistomatic (having greater frequency of the stomata on the abaxial surface). Preponderance of stomata on the abaxial surface is a coping strategies and a mechanism to reduce water loss through transpiration (Adegbite, 2008; Aworinde, 2009; McMullan, 2013; Zhigila et al., 2015).

The distribution of stomata on the upper and lower surface of the taxa revealed Paracytic and anomocytic types of stomata (Fig. 2). Generally, there is high frequency of Paracytic stomata in red, cream and stripped brown with 100\% each on both surfaces compared to anomocytic in black with $100 \%$ on both surface and stripped black with $50 \%$ on the abaxial surface. This confirms the intraspecific relationship within Bambara
Groundnut varieties. The presence of Anomocytic type of stomata made the black/Stripped black variety distinct from other species in the same genus. The Stomatal index ranges from $(1.00 \pm 24.11)$ on the abaxial surface of stripped brown (lowest value) while in stripped black it is highest with $(9.47 \pm 31.00)$ in the abaxial surface. This implies that the Stomatal index is highest on the abaxial surface in stripped black, red and cream varieties, while the lowest value is in the abaxial surfaces of stripped brown and black varieties. The difference in Stomatal index of the species are often a reflection of physiological responses to combination of environmental factors which could be useful in delimitation at the species level (Adegbite, 2008). Duncan Multiple Range Test (DMRT) - One-way ANOVA also revealed that there is no significant difference on the abaxial and the adaxial surface on 
the following parameters: Stomatal density, epidermal cell density and stomatal index, but significance difference exists $(\mathrm{P}<0.05)$ on some characters on the abaxial and the adaxial surface of stomatal size of the variety red, cream, stripped brown and stripped black. Stomatal sizes in the five varieties were shown in Table 1. However, the stomatal size of adaxial surface of black was the highest (54.18 \pm 22.17 ), while abaxial surface of stripped black showed the lowest (24.10 \pm 6.31$)$. Pataky (2017) had earlier reported that stomata whose guard cells are less than $15 \mu \mathrm{m}$ long are designated 'small' while those that have more than $38 \mu \mathrm{m}$ long are termed 'large'. In this study the stomatal sizes were small in red, stripped brown and stripped black varieties and the large sizes were found in black and cream varieties. There were significance differences within black and stripped black in the stomatal sizes. This could probably imply that the stomata have the tendency of opening the guard cells in black and cream (with large sizes of guard cells) more than red, stripped brown and stripped black (with small sizes of guard cells). Stomatal size (guard cell area) and stomatal index provide values that would serve as parameters for comparison among taxa which can be useful for identification of the studied taxa (Essiet et al., 2011). Stomatal size is often correlated with Stomatal density such that small stomata give high density and large stomata give low density (Metcalfe and Chalk, 2013; Abdulrahman and Oladele, 2004). This statement is in line with the findings from this work where adaxial surface of black varieties have the highest stomatal size with low stomatal density and the abaxial surface of stripped black varieties have lowest stomatal size with largest stomatal density (Chen et al., 2009; Alege et al., 2013). Stomatal density like index is also generally higher on the abaxial surfaces of all the five varieties. A remarkable distinguishable feature of trichomes was observed on the abaxial surface of red, cream and black varieties. There was absence of trichomes in stripped brown and stripped black varieties on both surfaces (Fig. 2).

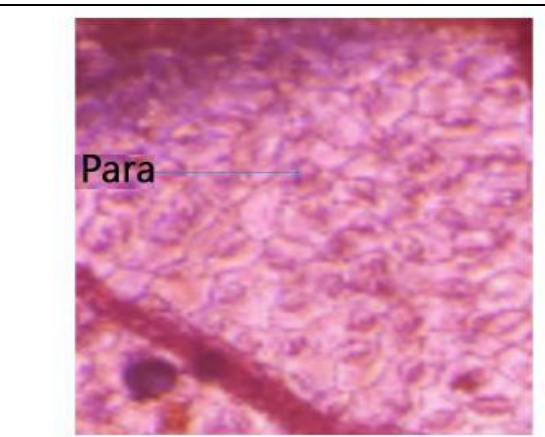

(A) The abaxial surface of red variety showing paracytic stomata and pentagonal epidermal cell shapes. $\mathrm{X} 400$

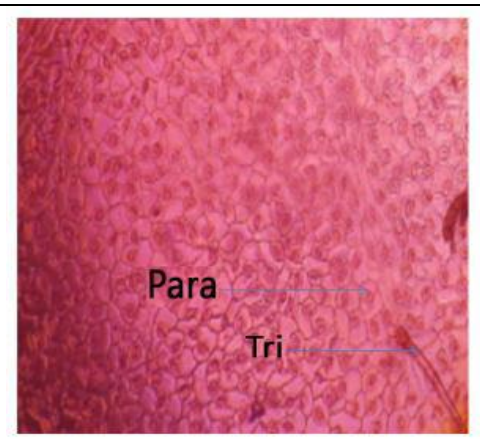

(B) The adaxial surface of red variety showing paracytic stomata and pentagonal epidermal cell shapes. X400

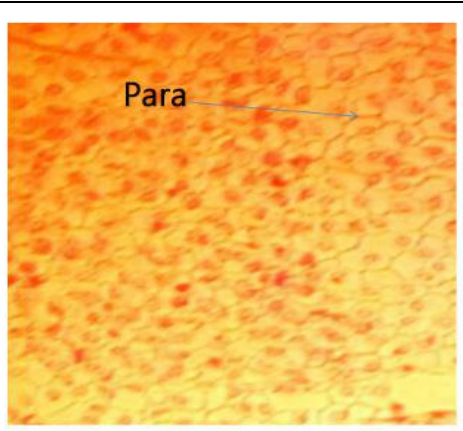

(C) Abaxial surface of white variety showing paracytic stomata and polygonal epidermal cell shape. X400

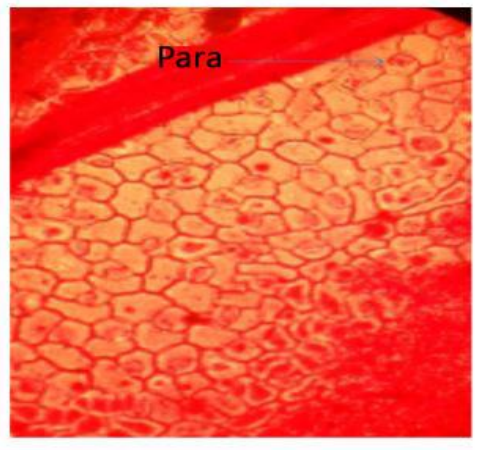

(D) Abaxial surface of white variety showing paracytic stomata and polygonal epidermal cell shape. X400

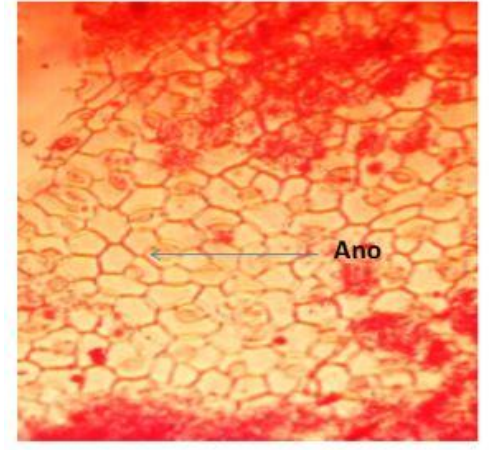

(E) Adaxial surface of black variety showing anomocytic stomata and polygonal shape. X400

Fig. 2: Micro-morphology of Bambara groundnut leaf epidermis. 
These trichomes are unicellular with the same shapes and sizes. Hence, according to Greulach (2013), abundant dead hairs on leaf surface have been thought to form a boundary layer of moist air, and generally thought to help keep the leaf cool and also to prevent rapid wind current from passing close to the surface and thus removing water vapour from transpiring and so reduce the rate of transpiration and living hairs could be expected to increase the evaporating surface greatly. Variation in trichome characteristics in these varieties is an inherent character because the varieties were collected from the same environment, of the same age, and of the same time. Hence, the absence and presence of trichomes in the taxa are of taxonomic importance and can be used to delimit these varieties from other varieties in the same genus. Esseitt et al. (2012) reported that trichome density can be reasonably employed for the delimitation of plant species. Apart from the taxonomic significance of trichomes, leaf trichomes contribute to plant resistance against herbivory (Dalin et al., 2008; Gopfert et al., 2010; Aschenbrenner et al., 2013).

There were polygonal epidermal cells shape present in all the varieties and straight and curved anticlinal cell wall pattern in all the varieties. The epidermal cell density on the adaxial surface is generally low $(45.67 \pm 7.51)$ and high on the abaxial surfaces (100.67 \pm 24.11). The results show a close relationship among the varieties. Olowokudejo (2010) also made similar observations in the genus Annona. Furthermore, the use of leaf epidermal features (epidermal cell, stomata and trichomes) in systematics has become popular and distinctive and have been used as a great taxonomic tool at the levels of family, genus and species. The works of Pandey (2009), Sharma et al. (2010), Gill and Keratela (1982), Edeoga and Osawe (1996), and Edeoga and Okoli (2001) are typical examples.

It was concluded that the presence of hypoamphistomatic leaves; two types of Stomatal complex types namely Paracytic and Anomocytic. Straight and curved anticlinal cell wall patterns with Polygonal epidermal cell shapes, presence of trichomes on the Abaxial surface of (red, cream and black,) and absence on both surfaces of (stripped brown and stripped black varieties) all contributed in delimiting the species. There was also no significant difference on the Abaxial and
Adaxial of the following parameters: Stomatal density, Epidermal cell density, Stomatal index, but significance difference exists $(\mathrm{P}<0.05)$ on some characters on the Abaxial and Adaxial surfaces of Stomatal size. There were also the presence of large Stomatal sizes in (cream and black), and small Stomatal sizes in (red, stripped brown and stripped black) varieties. The red, stripped brown and stripped black were better able to conserve water than cream and black varieties. These features were also found to be of good and reliable taxonomic use for delimiting the five varieties of Bambara Groundnut. All the varieties had water conserving properties, but red variety had the highest water conserving property of having both small size of stomata and trichomes.

It was recommended that the all five varieties of Bambara Groundnut. have water conserving properties, but red variety has the highest water conserving property of having both small size of stomata and trichomes, farmers should be cultivated in drought area to retain moisture by the environment. The results of this study shows that despite the numerous potentials in the crop, there is however a need to improve upon its utilization and market potentials, especially in developing countries of Africa, like Nigeria.

\section{Conflict of interest statement}

Authors declare that they have no conflict of interest.

\section{References}

Abba, H.M., Abdullahi, A., Yuguda, U. A., 2018. Leaf epidermal anatomy of Ipomoea carnea Jacq sampled from selected areas in Gombe State, Nigeria. Bayero J. Pure Appl. Sci. 11(1), 148-154.

Abdulrahaman, A. A., Oladele, F. A., 2004. Types, density and frequencies of trichomes in some Nigerian vegetable species. Nig. J. Pure Appl. Sci. 19, 1653-1658.

Abdulrahaman, A. A., Oladele, F. A., 2010. Leaf micro-morphology of some Amaranthus. Nig. J. Pure Appl. Sci. 23, 2136-2143.

Abdulrahman, A.A., Oladele, F. A., 2003. Stomatal complex types, stomatal size, density and index in some vegetable species in Nigeria. Niger. J. Bot. 16(2), 144-150. 
Adegbite, A. E., 2008. Leaf anatomical studies in some species of the tribe Cichorieae (Asteraceae) in Nigeria. Compar. Newslett. 46, 49-58.

Alege, G. O., Mustapha, O. T., Ojo, S., Awosemo, B. M., 2013. The morphological, proximate and nutrient sources. Global J. Biosci. Biotechnol. 2(1), 12-16.

Aschenbrenner, A. K., Horakh, S., Spring, O., 2013. Linear glandular trichomes of Helianthus (Asteraceae): Morphology, localization, metabolite activity and occurrence. Ann. Bot. Plants.5:028. doi:10.1093/aobpla/plto28

Aworinde, D. O., Ogundairo, B. O., 2009. Leaf epidermal micromorphology in some members of Solanum L. (Solanaceae) in Nigeria. Univ. Zambia J. Sci. Technol. 13(2), 29-40.

Borget, M., 1992. Food Legumes. In: The Tropical Agriculturalist, CTA Macmillan.

Brink, M., Ramolemana, G. M., Sibuga, K. P., 2006. Vigna subterranea (L.) Verdc. In: Plant Resources of Tropical African 1. Cereals and Pulses (Eds.: Brink, M., Belay, G.). PROTA Foundation, Wageningen, Netherlands, pp.213218.

Chen, G., Sun, W., Sun, H., 2009. Morphological characteristics of leaf epidamis and size variation of leaf, flower and fruit in different ploidy levels in Buddleja macrostachya (Buddlejaceae). J. Syst. Evol. 47(3), 231-236.

Dalin, P., Jon, A., Gren, J. A., Bjorkman, C., Huttunen, P., 2008. Leaf trichome formation and plant resistance to herbivory. In: Induced Plant Resistance to Herbivory (Ed.: Schaller, A.), Springer Science+Business Media B.V.

Dilcher, D. L., 1974. Approaches to the identification of angiosperm leaf remains. Bot. Rev. 40(1), 1-157.

Directorate Plant Production (DPP), 2011. In Collaboration with Agric Resource Centre (ARC).

Doku, E. V., 1995. University of Ghana. In: Proceedings of the Workshop on Conservation and Improvement of Bambara groundnut (Vigna subterranea (L.) Verdc) Harare Zimbabwe.

Ecoport, 2009. Ecoport database. Ecoport.

Edeoga, H. O., Okoli, B. E., 2001. Midrib anatomy and systematics in Dioscorea L. (Dioscoreaceae). Rec. Res. Plant Anat. Morph. 19, 191-195.

Edeoga, H. O., Osawe, I. O., 1996. Cuticular studies of some Nigerian species of Senna. Tourn. Ex Mill (Syn Cassia Journ. Ex. L.) Leguminosae Caesalpinoideae. Acta Phytotax. Geobot. 47, 41.

Esseitt, U. A., Illoh, H. C., Udoh, U. E., 2012. Leaf epidermal studies of three species of Euphobia in Akwa-Ibom State. Adv. Appl. Sci. Res. 3(4), 2857-2862.

Franco, C., 1939. Relation between chromosome number and stomata in Coffea. Bot. Gat. 100, 817-823.

Gibbon, D., Pain, A., 2015. Crops of the Drier Regions of the Tropics. Longman Scientific and Technical, Longman Group UK Ltd.

Gill, L. S., Karatela, Y. Y., 1982. Epidermal structure and stomatal ontogeny in some Nigerian Curcubitaceae. Willdenowia 12, 303-310.

Goli, A. E., 1995. Characterization and evaluation of IITA's Bambara groundnut collection. In: Proceedings of the Workshop on Conservation and Improvement of Bambara Groundnut (Vigna subtarranea (L.) Verdc.) (Eds.: Begemann, J. H., Mushonga, J.). International Plant Genetic Resources Institute (IPGRI), Zimbabwe.

Goli, A. E., Ng, N.Q., 1988. Bambara groundnut multi-location yield trial. Pp. 11-12 in Annual Report, Genetic Resources Unit, IITA.

Gopfert, J. C., Bulow, A. K., Spring, O., 2010. Identification and functional characterization of a new sunflower germacrene A synthase (HaGAS3). Natural Prod. Commun. 5, 709-715.

Greulach, V. A., 1973. Plant Function and Structure. MacMillan Publishing Company, Lincoln, United Kingdom, 432p.

Hardie, J., 2009. Autumn leaves seen through herbivore eye. Proc. Royal Soc. Biol. Sci. 276, 121.

Linnemann, A. R., Azam-Ali, S. N., 1993. Bambara groundnut (Vigna subterranea) literature review: A revised and updated bibliography. Tropical Crops Communication No. 7, Wageningen Agricultural University.

Mcmullan, M., Livsey, J., 2013. The Chileman. Bolvian Gold (PI 260579): Baccatum, Bolivia.

Mekbib, F., 2006. Farmer and formal breeding of sorghum (Sorghum bicolor (L.) Moench. and the implications for integrated plant breeding. Euphytica 152, 163-176.

Metcalfe, C. R., Chalk, L., 1988. Anatomy of Dicotyledons. $2^{\text {nd }}$ Edn. Vol 1. Clarendon Press, pp.10-16.

Nishitani, T., Muraki, K., Inouye, J., 1988. Effects of day length on the flowering and fruiting in 
Bambara groundnut (Vigna subterranea (L.) Verdc.). Jap. J. Trop. Agric. 32, 75-79.

Nti, C. A., 2009. Effects Bambara nut (Vigna subterranea) variety and processing on the quality and consumer appeal for its products. Int. J. Food Sci. Technol. 44(11), 2234-2242.

Obiremi, E. O., Oladele, F. A., 2001. Water conserving stomatal system in selected citrus species. S. Afr. J. Bot. 67, 258-260.

Olowokudejo, J. D., 2010. Comparative morphology of leaf epidermis in the genus Annona (Annonaceae) in West Africa. Phytomorphol. 40, 407-422.

Omoikhoje, S. O., 2008. Assessment of the nutritive value of Bambara groundnut as influenced by cooking time. Livest. Res. Rural Dev. 20(4), Article \#55.

Pandey, S. N., Misra, S. P., 2009. Taxonomy of Angiosperms. Ane Books Pvt. Ltd., Parwana Bhawa, Darya Ganj, New Delhi, India.

Pataky, S., 2007. Leaf epidermis of Salix. In: Anatomy of the Dicotyledons (Eds.: Metcalfe, C.R., Chalk, L.). Vol. 1, $2^{\text {nd }}$ Edn. Clarendon press, Oxford, 110p.

Ren, B., Zhu, X. Y., Jlang, Y. C., 2007. Systematic significance of leaf epidermal features in Apios and Cochlianthus (Leguminosae). Acta Phytotax. Sinica 45, 274-284.

Saheed, S. F., Illoh, H. C., 2010. A taxonomic study of some species in Cassiinae (Leguminosae) using leaf epidermal characters. Not. Bot. Hort. Agrobot. 38(1), 21-27.
Sharma, A., Sehrawai, S. K., Singhrot, R. S., Tele, A., 2010. Morphological chemical characterization of Psidium species. Not. Bot. Hort. Agrobot, 38(1), 28-32.

Swanevelder, C. J., 2008. Bambara food for Africa: (Vigna subterranea) Bambara groundnut. National Department of Agriculture, South Africa.

Tanimu, R. S., Aliyu, L., 2010. Genotypic variability in Bambara groundnut cultivars at Samaru, Nigeria. In: Proceedings of the 17th Annual Conference of Genetic Society of Nigeria (Ed.: Obigbeshan, I. O.). Institute for Agricultural Research and Training. Obafemi Awolowo University, Nigeria, pp.54-6o.

Tweneboah, C. K., 2000. Modern Agriculture in the Tropics, Food crops. Co-Wood Publishers.

Van Wyk, A. E., Robbertse, P. J., Kok, P. D., 2008. The genus Eugenia L. (Myrtaceae) in South Africa: the structure and taxonomic value of stomata. Bot. J. Linn. Soc. 84(1), 41-56.

Watson, L., 2006. The taxonomic significance of certain anatomical observation on Ericaceae. New Phytol. 63(3), 274-280.

Wilkinson, H. P., 2009. Leaf anatomy of various Anacardiaceae with reference to the epidermia. Ph.D. Thesis, University of London, London.

Zhigila, D.A., Sawa, F. B. J., Aluko, T. A., Oladele, F. A., Abdulrahaman, A. A., 2015. Leaf epidermal anatomy in five varieties of Capsicum annuum L. Solanaceae. Amer. J. Exp. Agric. 5(4), 392-399.

\section{How to cite this article:}

Abba, H. M., Umar, B. A., Mohammed, I., 2019. Leaf epidermal anatomy of selected varieties of Bambara groundnut in Gombe State, Nigeria. Int. J. Curr. Res. Biosci. Plant Biol. 6(9), 44-52.

doi: https://doi.org/10.20546/ijcrbp.2019.609.006 